\title{
Combined Effects of Weight Training and Aerobic Exercise Accompanied by Normal and Low-Calorie Diets on Fat Percentage of Young Women
}

\author{
Padli*, Yanuar Kiram, Sayuti Syahara, Heru Syarli Lesmana \\ Faculty of Sports Science, Universitas Negeri Padang, Padang, Indonesia
}

Received August 4, 2020; Revised September 28, 2020; Accepted October 19, 2020

\section{Cite This Paper in the following Citation Styles}

(a): [1] Padli, Yanuar Kiram, Sayuti Syahara, Heru Syarli Lesmana, "Combined Effects of Weight Training and Aerobic Exercise Accompanied by Normal and Low-Calorie Diets on Fat Percentage of Young Women," International Journal of Human Movement and Sports Sciences, Vol. 8, No. 5, pp. 283 - 291, 2020. DOI: 10.13189/saj.2020.080517.

(b): Padli, Yanuar Kiram, Sayuti Syahara, Heru Syarli Lesmana (2020). Combined Effects of Weight Training and Aerobic Exercise Accompanied by Normal and Low-Calorie Diets on Fat Percentage of Young Women. International Journal of Human Movement and Sports Sciences, 8(5), 283 - 291. DOI: 10.13189/saj.2020.080517.

Copyright $@ 2020$ by authors, all rights reserved. Authors agree that this article remains permanently open access under the terms of the Creative Commons Attribution License 4.0 International License

\begin{abstract}
Sports with a combination of weight training and aerobics are expected to be an alternative to increase students' desire to exercise and reduce fat more effectively. Therefore, this study aims to determine the potential of combined aerobic exercise and weight training to be an alternative to reducing body fat combined with a normal diet program with a low calorie diet program. This research is a quantitative quasi-experimental research with pre-test and post-test control group design. With a total of 60 participants, which were divided into two groups, namely the experimental group using the low calorie diet program and the control group using the normal diet program. All data obtained were searched for the mean and the differences between the two body fat reduction programs using independent sample t-test. The combination of aerobic exercise and weight training can reduce participants' body weight, body fat and waist circumference, both in the normal diet and low-calorie diet groups. However, the low calorie diet program is more effective than the normal diet. This is evidenced by the significant reduction in body fat and strengthened by the independent sample t-test which is seen from the $t$ value which is greater than the $t$ table and the significance value obtained is less than 0.025 , namely 0.012 for weight loss, 0.011 for a decrease in the percentage of fat, and 0.010 for a decrease in waist circumference. It is concluded that there is a difference in the decrease in the percentage of fat in the normal diet and low calorie diet groups.
\end{abstract}

Keywords Aerobics, Normal Diet, Low Calorie Diet, Weight Training

\section{Introduction}

Obesity and overweight are increasing both in developed countries like the USA and Europe and in developing countries such as in Asia, namely Iran, Sri Lanka and Bangladesh including Indonesia. Over the past 3 decades, in general, adults who are overweight and obese throughout the world have increased significantly [1]. The problem of obesity also affects children. In the United States, in the range 2011-2014, as many as $17 \%$ of cases of obesity are commonly found in children, and 5.8\% are classified as cases of extreme obesity found in young people aged 2-19 years [2-5]. The National Health Research Data (Riskesnas) in 2016 shows that the adult population over 18 years who are overweight or obese is 20.7\%. That number shows a rapid increase from 2013 when the overweight population reached $15.4 \%$. A Global Burden of Diseases study published in the journal Lancet in 2014 revealed that there were 10 countries with the highest obesity rates in the world and Indonesia ranked 10th.

Obesity is a pathological state because of the accumulation of excess fat than is needed for bodily functions [6, 7].There are so many risks of health problems 
that can occur in children or adolescents who are obese. Children with obesity can experience problems with the heart and blood vessel (cardiovascular) systems, namely hypertension and dyslipidemia (abnormalities in cholesterol) [8-11]. Children can also experience liver function disorders where there is an increase in Serum Glutamic Oxaloacetic Transaminase (SGOT) and Serum Glutamic Pyruvic Transaminase (SGPT) and an enlarged heart. Gallstones can also be formed and diabetes (diabetes mellitus). In the respiratory system, disorders can occur, which affects lung function, snoring during sleep, and often experience obstruction of the airway (obstructive sleep apnea). This will make the child less concentrated on capturing his lessons because he is sleepy and will later be feared, which can affect his performance in school [12].

Some ways to deal with obesity include exercise, diet and psychological therapy. Provision of dietary therapy in obese patients aims to reduce energy intake and increase expenditure so as to achieve ideal body weight. For people who are obese, it is recommended to reduce their food intake by 200-300 kcal / day, with a standard diet of around 1000-1200 kcal / day [13-16 ]. A low-calorie balanced diet must be balanced with exercise. Regular and continuous physical exercise with a gradual increase in load can reduce the percentage of body fat so that body weight also decreases $[17,18]$. Based on this opinion, exercise is the best way to lose weight. According to experts, the type of exercise that is most suitable for obese individuals is aerobic activity. Aerobic activities are sports that burn fat when the activity is carried out. Aerobic activities include all types of bodily activities that use high amounts of oxygen. Treadmills, up and down stairs, swimming, cycling, aerobics are aerobic activities and support fat burning. Burning fat activities need to be done with a specific heart rate target of 50\% -75\% DNM (maximum pulse rate) for a period of 45-75 minutes so that fat in the body can be burned [19]. That's when the body release fat cells in fat bags as a source of energy.

Weight training is a method of resistance training using weights as a tool to improve physical condition, including physical fitness and general health. Identical weight training to build muscle leads to formation for bodybuilders, but research shows that weight training can play a role in the process of reducing body fat. Weight training is a superior way to reduce body fat and keep fat back in stock [20, 21]. Muscles make metabolism more active. The more muscle you have, the faster your metabolism rate, the more calories you burn, so it is easier for your body to get a slender, firmer appearance. "Combining aerobic exercise with weight training is much more effective at reducing body fat. Combining weight training (weight training) with other sports, will produce maximum fat burning. The trick, weight training (weight training) for 30-45 minutes to burn calories from carbohydrates. Use these moments to do sports in addition to weight training with a heart rate of about $65 \%$. This will optimize the burning of body fat [22].

When undergoing a diet program, exercise is one of the crucial factors. High school students who are still in their teens tend to be lazy to exercise because it drains a lot of energy and causes fatigue. Obese adolescents tend to prefer regulating diets without doing exercise to reduce body fat. The form and type of exercise also determine the enthusiasm of teenagers to exercise. Sports with a combination of weight training and aerobics are expected to be an alternative to increase students' desire to exercise and reduce fat more effectively. Therefore, this study aims to determine the potential of combined aerobic exercise and weight training as an alternative to reducing body fat combined with a normal diet program with a low calorie diet program.

\section{Materials and Methods}

This research is a quasi-experimental research with pre-test and post-test control group design. That was done to investigate causal hypotheses about causes that could be manipulated by comparing one or more experimental groups that were treated with one comparison group that was not treated [23, 24]. The design of this study was applied because it was in accordance with the objectives of the study, whose the aim was to find out the potential of combined aerobic exercise and weight training as an alternative to reducing body fat. This research uses descriptive statistics in the form of mean, min, max, category and uses inferential statistics. The inferential statistics used are independent sample t-tests and anova.

Table 1. Pretest and Posttest Non-Equivalent Control Group Design

\begin{tabular}{cccc}
\hline Group & Posttest & Treatment & Posttest \\
\hline Experimental & $\mathrm{O}_{1}$ & Normal Diet & $\mathrm{O}_{1}$ \\
Control & $\mathrm{O}_{2}$ & Low Calorie Diet & $\mathrm{O}_{2}$ \\
\hline
\end{tabular}

Subjects in this study were taken from three senior high school students in Padang City, as many as 110 female students, with details of 36 students in senior high school 1 Padang, 36 students in senior high school 11 Padang, and 38 students in senior high school 11 Padang who were overweight $20 \%$ of the BMI standard (obesity). The sampling was based on cluster sampling technique. In cluster sampling two or more elements or two units or more are included in the sample at each sample location [25]. The inclusion of two or more units / elements in each sample location intensified sampling efforts at each sample location. Cluster sampling was chosen because it can facilitate research to collect data from a large research area. In the experimental group there were 18 students and in the control group there were also 18 students of senior high schools 1 and 9 Padang, while for senior high schools 11 Padang, in the experimental group there were 19 students and in the control group there were also 19 students. In the 
experimental group using a low calorie diet program and in the control group using a normal diet program.

According to Indonesian Government regulation no. 36 of 2009, that adolescent girls must have an ideal body weight level (listed in table 2) and this is a very credible reference for teachers or trainers so that students live well. The obesity category in this study is based on the ideal weight in accordance with Law no. 36 of 2009 concerning Health which can be seen in table 2 .

Table 2. Weight categories of Indonesian female adolescents

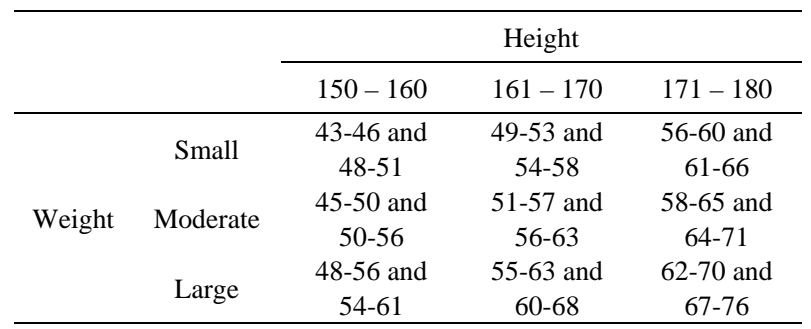

Meanwhile, the participants' responses in adjusting training protocols and equipment can be seen in table 3 below

Table 3. Categories of participant responses to training protocols and equipment

\begin{tabular}{cc}
\hline Category & Interval \\
\hline $0.0-20.0$ & Very Easy \\
$20.1-40.0$ & Easy \\
$40.1-60.0$ & Enough \\
$60.1-80.0$ & Difficult \\
$80.1-100.0$ & Very difficult \\
\hline
\end{tabular}

All samples performed a combined weight training and aerobic exercise. Weight training is done for 15-25 minutes with a load of $30 \%-75 \%$ of 1 RM (Maximum Reps or Best Achievement) and 10-15 reps are performed 2-3 sets of each muscle. Weight training means Lat Pull Down, Shoulder Press, Deadlift and Squat. Then proceed with aerobic exercise by walking on the treadmill for 12-25 minutes with an intensity of $60 \%-75 \%$ DNM (Maximum Pulse), the treadmill used in this study is the electric treadmill OB-1057 with a maximum speed of $10 \mathrm{~km} /$ hour with a size of $40 \mathrm{~cm} \times 140 \mathrm{~cm}$. Given a good knowledge of using electric treadmill tools OB-1057, it is used by adjusting the speed starting from the lowest and increasing to a maximum pulse intensity of $60-75 \%$ for $12-25$ minutes, then using a barbell with a weight of $2.5 \mathrm{~kg}$ to perform movements Sholder press where the participant sits in a perfect position, then the hands form a 90 degree seat and when pushing the hands up the participants exhale and when the hands go down the participants inhale until their hands form a 60 degree angle with the body, for exercises using Lat Pull Down by sitting on the Lat Pulldown tool and grasp the bar in an overhand grip slightly over shoulder width. The arms should be perfectly straight and the torso and Pull the shoulder blades down and back, and pull the bar toward the chest. Pause for a moment, then return to the starting position slowly. Take a breath when inhaling the exhalation bar and when returning to the starting position take a breath. While squats are done by opening your feet shoulder width apart, forming a 90 degree squatting position, flat back position and resting on your heels; repeat continuously until you are according to the given target; breathe when going down; take a breath and go up and exhale.

The research treatment was given as many as 16 meetings for 1 month, which had to be followed by the sample. Before starting the exercise the sample was given one week for adaptation to the training equipment and protocol. The low-calorie diet group was instructed to adjust the diet according to the principles of a low-calorie diet by limiting energy-dense foods, such as pastries that contain lots of simple carbohydrates and fat and fried foods. This diet maintains a balance of carbohydrates, fats, protein and vitamin and mineral needs. Energy intake is reduced by 500 Kcal per day from normal needs. Normal protein or slightly above normal requirements, namely $1-1.5 \mathrm{~g} / \mathrm{kg}$ body weight / day or $15-20 \%$ of normal needs. Fat $15-20 \%$ of total energy. Carbohydrates are slightly lower, namely $55-65 \%$ of the total energy requirement for consumption. Percentage of body fat was measured before and after exercise using the Biometrical Impedance Analysis (BIA) tool, a measurement method with a scale and a handle-shaped device (Schutz, 2002; Kyle, 2004; Lee, 2008; Sivapahty, 2013; Gontarev, 2014; Abulmeaty, 2016). Here the researchers used the Biometrical Impedance Analysis (BIA) tool with the OMRON HBF 375 type.

A nutritionist is tasked with making a low-calorie diet and a normal diet for 30 days, which will be applied to the sample. One example of a normal diet used in this study is as follows: breakfast: 2 slices of whole wheat bread, 2 boiled eggs and 1 cup of coffee; Lunch: Brown rice, 2 chicken breasts, 2 cups of carrots; Dinner: Brown rice, 2 chicken breasts, a bowl of spinach; Snack: a handful of almonds. For a low calorie diet, eat the following menu, Breakfast: Fruit slices with yogurt + 1-2 pieces of whole wheat bread and 1 boiled egg; Lunch: Boiled chicken breast with mashed potatoes + a bowl of spinach; Dinner: vegetable salad and low fat milk +3 tablespoons oatmeal + 1 boiled egg; Snack: a handful of almonds. An explanation of the sample was given by a nutritionist before carrying out the research and was instructed to commit to running the food menu program. The consumption of sample foods will be recorded through daily questionnaires collected before the training process begins. Samples that do not run the research protocol will be excluded from the research process. After the data is collected then the data is compiled, then the data is processed using the independent sample t-test and ANOVA analysis technique with SPSS 21. 


\section{Results and Discussion}

The research findings are described in this section. For the response of participants in trying to adapt to training equipment and protocols, it can be seen in Table 4 below

Table 4. Results of participant responses in trying out training equipment and protocols

\begin{tabular}{|c|c|c|c|c|c|c|}
\hline \multicolumn{4}{|c|}{ Category } & \multirow{2}{*}{ Mean } & \multirow{2}{*}{ Min } & \multirow{2}{*}{ Max } \\
\hline Response & Range & f & $\%$ & & & \\
\hline $\begin{array}{l}\text { Very } \\
\text { easy }\end{array}$ & $00.0-20.0$ & 0 & 0.0 & & & \\
\hline Easy & $20.0-40.0$ & 2 & 1.8 & & & \\
\hline Enough & $40.1-60.0$ & 88 & 80.0 & 54.8 & 39 & 96 \\
\hline Difficult & $60.1-80.0$ & 13 & 11.8 & & & \\
\hline $\begin{array}{c}\text { Very } \\
\text { difficult }\end{array}$ & $80.1-100.0$ & 7 & 6.4 & & & \\
\hline Total & & $\begin{array}{c}11 \\
0\end{array}$ & 100 & & & \\
\hline
\end{tabular}

From table 4, which came from 110 respondents from the senior high school in Padang City after they were obtained and the results using the SPSS 21 application program, the participants trying the equipment and training protocol had the dominant result is good with a percentage of $80.0 \%$ of the 88 participants from a total of 110 participants. From 110 students, the mean results were 54.8, the maximum value was 96 , and the minimum value was 39.

Meanwhile, the results of the pretest (see table 5-7) and posttest (see table 8-10) in showing the differences in weight training and aerobics in reducing body fat through normal diet programs and students' low calorie diet programs are presented as follows.

Table 5. Pretest results of participants with a height of $150-160$

\begin{tabular}{cccc}
\hline Indicator & Groups & Category & Mean \\
\hline \multirow{2}{*}{ Weight $(\mathrm{Kg})$} & Experiment & Large & 58.3 \\
& Control & Large & 58.4 \\
\hline \multirow{2}{*}{ Fat Percentage } & Experiment & & 34.4 \\
& Control & & 34.9 \\
\hline \multirow{2}{*}{ Waist size } & Experiment & & 86 \\
& Control & & 86 \\
\hline
\end{tabular}

Table 6. Pretest results of participants with a height of $161-170$

\begin{tabular}{cccc}
\hline Indicator & Groups & Category & Mean \\
\hline \multirow{2}{*}{ Weight $(\mathrm{Kg})$} & Experiment & Large & 65.7 \\
& Control & Large & 65.8 \\
\hline \multirow{2}{*}{ Fat Percentage } & Experiment & & 34.6 \\
& Control & & 34.7 \\
\hline \multirow{2}{*}{ Waist size } & Experiment & & 87 \\
& Control & & 87 \\
\hline
\end{tabular}

Table 7. Pretest results of participants with a height of $171-180$

\begin{tabular}{cccc}
\hline Indicator & Groups & Category & Mean \\
\hline \multirow{2}{*}{ Weight $(\mathrm{Kg})$} & Experiment & Large & 74.2 \\
& Control & Large & 74.3 \\
\hline \multirow{2}{*}{ Fat Percentage } & Experiment & & 34.5 \\
& Control & & 34.6 \\
\hline \multirow{2}{*}{ Waist size } & Experiment & & 88 \\
& Control & & 88 \\
\hline
\end{tabular}

From table 5-7, it can be seen that there is no difference between the experimental and control classes, namely both have large weight / obesity categories.

Table 8. Posttest results for participants with a height of $150-160$

\begin{tabular}{cccccc}
\hline Indicator & Groups & Category & Mean & Min & Max \\
\hline Weight & Experiment & Moderate & 50.3 & 2 & 8 \\
$(\mathrm{Kg})$ & Control & Large & 56.4 & 1 & 2 \\
\hline Fat & Experiment & & 23.4 & 7 & 11 \\
$\begin{array}{c}\text { Percentage } \\
(\%)\end{array}$ & Control & & 28.9 & 4 & 6 \\
\hline Waist size & Experiment & & 81 & 1.5 & 5 \\
$(\mathrm{~cm})$ & Control & & 82 & 1 & 4 \\
\hline
\end{tabular}

Table 9. Posttest results for participants with heights $161-170$

\begin{tabular}{cccccc}
\hline Indicator & Groups & Category & Mean & Min & Max \\
\hline Weight & Experiment & Moderate & 50.3 & 2 & 8 \\
$($ Kg) & Control & Large & 56.4 & 1 & 2 \\
\hline Fat & Experiment & & 23.4 & 7 & 11 \\
$\begin{array}{c}\text { Percentage } \\
(\%)\end{array}$ & Control & & 28.9 & 4 & 6 \\
\hline Waist size & Experiment & & 81 & 1.5 & 5 \\
$(\mathrm{~cm})$ & Control & & 82 & 1 & 4 \\
\hline
\end{tabular}

Table 10. Posttest results for participants with a height of $171-180$

\begin{tabular}{cccccc}
\hline Indicator & Groups & Category & Mean & Min & Max \\
\hline Weight & Experiment & Moderate & 65.1 & 3 & 9 \\
$($ Kg) & Control & Large & 71.6 & 1 & 3 \\
\hline Fat & Experiment & & 22.6 & 7 & 12 \\
$\begin{array}{c}\text { Percentage } \\
(\%)\end{array}$ & Control & & 27.7 & 3 & 7 \\
\hline Waist size & Experiment & & 83 & 2 & 5 \\
$(\mathrm{~cm})$ & Control & & 84 & 1.5 & 4 \\
\hline
\end{tabular}

The results of descriptive statistics show that there is a gradual decrease in body weight, fat percentage and waist circumference. The decrease of each variable occurs gradually from pretest to posttest. The effect of treatment on the percentage of fat was analyzed by comparing the pretest and posttest data in the normal diet and low calorie diet groups. All statistical processing uses the IBM SPSS Statistics 24 program. 
From table 8-10, we can see that the experimental class is superior in reducing body fat, both from body weight, fat percentage, and circumference owned. In the experimental class, the weight loss was $8 \mathrm{~kg}$, while the control class was $3 \mathrm{~kg}$, the percentage of body fat was also outperformed by the experimental class by being able to reduce it by $11 \%$, while the control class was able to reduce it by $6 \%$. Then for waist circumference the experimental class was also outperformed by $5 \mathrm{~cm}$ while the control class was $4 \mathrm{~cm}$. Based on this, it can be seen that the use of weight training with aerobics assisted by a low calorie diet program is more effective than the use of weight training with aeribok combined with a normal diet program. However, this has not been able to strengthen the difference between the use of weight training with aerobics assisted by a low calorie diet program with a normal diet program, so inferential testing is carried out using ANOVA (Tables 11-14) and independent sample t-test in table 15.

Table 11. Results of a normal diet with a combination of weight training and aerobics in Padang City Senior High School

\begin{tabular}{cccccc}
\hline \multicolumn{5}{c}{ ANOVA } \\
\hline & $\begin{array}{c}\text { Sum of } \\
\text { Squares }\end{array}$ & df & $\begin{array}{c}\text { Mean } \\
\text { Square }\end{array}$ & F & Sig. \\
\hline $\begin{array}{c}\text { Between } \\
\text { Groups }\end{array}$ & 358.847 & 2 & 179.423 & 14.237 & .000 \\
Within Groups & 18009.426 & 1429 & 12.603 & & \\
Total & 18368.273 & 1431 & & & \\
\hline
\end{tabular}

Anova test was used to see differences in the normal diet program at three different schools in Padang City. The results of data analysis in table 11 on the normal diet program obtained a significance value of 0.00 or more smaller than 0.05 with a significant level of 0.05 . So it can be concluded that there is a significant average difference between participants in senior high school 1 Padang, participants in senior high school 9 Padang, and participants in senior high school 11 Padang measured based on the diet program carried out.

In connection with the difference in the average between the three schools in Padang City for the normal diet program, to see the significant difference in the average success of the normal diet program carried out by the participants, the Tukey post hoc test was carried out. Based on the results of the analysis that has been done, the results are as shown in table 12 below:

Table 12. Post hoc using Tukey on a normal diet program

\begin{tabular}{cccc}
\hline \multicolumn{4}{c}{ Normal Diet Program } \\
\hline \multicolumn{3}{c}{ Tukey HSD $^{\mathrm{a}, \mathrm{b}}$} \\
\hline \multirow{2}{*}{ SEKOLAH } & $\mathrm{N}$ & \multicolumn{2}{c}{ Subset for alpha $=0.05$} \\
\cline { 3 - 4 } & & 36 & 26.7349 \\
\hline Senior High School 1 & 36 & \\
\hline Senior High School 9 & 36 & & 28.0876 \\
\hline Senior High School 11 & 38 & & 28.1086 \\
\hline Sig. & & 1.000 & .997 \\
\hline
\end{tabular}

Based on Table 12, it can be concluded that there is a significant difference in the group average between senior high schools in Padang City. Furthermore, there is also a significant difference in the group mean between senior secondary schools in 9 Padang cities and senior high schools in 11 Padang cities. The smallest group average in senior high school in Padang City is 26.7349, followed by senior high school in 9 Padang cities with a group average of 28.0876 and the largest average senior high school 11 in Padang is 28.1086 .

Table 13. Results of a low calorie diet with a combination of weight training and aerobics in Padang City Senior High School

\begin{tabular}{cccccc}
\hline \multicolumn{5}{c}{ ANOVA } \\
\hline & $\begin{array}{c}\text { Sum of } \\
\text { Squares }\end{array}$ & Df & $\begin{array}{c}\text { Mean } \\
\text { Square }\end{array}$ & F & Sig. \\
\hline $\begin{array}{c}\text { Between } \\
\text { Groups }\end{array}$ & 550.384 & 2 & 275.192 & 8.097 & .000 \\
$\begin{array}{c}\text { Within Groups } \\
\text { Total }\end{array}$ & 48568.529 & 1429 & 33.988 & & \\
\hline
\end{tabular}

Anova test was used to see differences in low calorie diet programs in three different schools in Padang City. The results of data analysis in table 13 on the low-calorie diet program obtained a significance value of 0.00 or less than 0.05 with a significant level of 0.05 . So it can be concluded that there is a significant average difference between participants in senior high school 1 Padang, participants in senior high school 9 Padang, and participants in senior high school 11 Padang measured based on the diet program carried out.

In connection with the difference in the average between the three schools in Padang City for the normal diet program, to see the significant difference in the average success of the normal diet program carried out by the participants, the Tukey post hoc test was carried out. Based on the results of the analysis that has been carried out, the results are as shown in table 14 below:

Table 14. Post has been using Tukey on a low calorie diet program

\begin{tabular}{cccc}
\hline \multicolumn{4}{c}{ Low Calorie Diet Program } \\
\hline \multicolumn{4}{c}{ Tukey HSD ${ }^{\mathrm{a}, \mathrm{b}}$} \\
\hline \multirow{2}{*}{ SEKOLAH } & $\mathrm{N}$ & \multicolumn{2}{c}{ Subset for alpha $=0.05$} \\
\cline { 3 - 4 } & & 1 & 2 \\
\hline Senior High School 1 & 36 & 34.0418 \\
\hline Senior High School 9 & 36 & & 35.2789 \\
\hline Senior High School 11 & 38 & & 35.4279 \\
\hline Sig. & & 1.000 & .918 \\
\hline
\end{tabular}

Based on Table 14, it can be concluded that there is a significant difference in the group average between senior high schools in Padang city. Furthermore, there is also a significant difference in the group mean between senior secondary schools in 9 Padang cities and senior high schools in 11 Padang cities. The smallest group average in senior high school 1 in Padang City is 34.0418, followed by senior high school 1 Padang city with an average group of 35.2789 and the largest average senior high school 11 Padang City is 35.4279. 
Combined Effects of Weight Training and Aerobic Exercise

Accompanied by Normal and Low-Calorie Diets on Fat Percentage of Young Women

Table 15. Results of the Independent sample t-test for participants' weight loss

\begin{tabular}{|c|c|c|c|c|c|c|}
\hline & \multirow{2}{*}{$\mathrm{T}$} & \multirow{2}{*}{ Df } & \multirow{2}{*}{ Sig } & \multirow{2}{*}{ Std. Deviation } & \multicolumn{2}{|c|}{ 95\% confidence interva } \\
\hline & & & & & Lower & Upper \\
\hline \multirow{2}{*}{ Weight loss } & 14.163 & 110 & 0.012 & 2.51 & 12.236 & .4120 \\
\hline & 14.163 & 76.321 & 0.012 & 1.83 & 11.935 & .5615 \\
\hline \multirow{2}{*}{ Decrease in fat percentage } & 14.271 & 110 & 0.011 & 2.73 & 12.344 & .4235 \\
\hline & 14.271 & 77.641 & 0.011 & 1.92 & 11.998 & .5715 \\
\hline \multirow{2}{*}{ Decrease in waist circumference } & 14.359 & 110 & 0.010 & 2.61 & 12.297 & .4310 \\
\hline & 14.359 & 76.952 & 0.010 & 1.88 & 11.976 & .5698 \\
\hline
\end{tabular}

From table 15 the value obtained (t count) can be seen The value of $t$ table can be seen in the $t$ table with a significance value of 0.025 (2-sided test) with 110 degrees of freedom (df). In this study, the $t$ table results were 1.98177. However, the $t$ value can be seen in table 10 . (Column t) is 14.163 for a reduction in body weight, 14,271 for a decrease in fat percentage, and 14,359 for a decrease in waist circumference. The criteria for testing the hypothesis in this study if the $t$ table value is smaller than the t count or the sig value obtained is smaller than the specified (0.025), then there is a difference [32]. Therefore, based on the results obtained, $t$ count is greater than $t$ table; there is a comparison between the two ration methods used. And it is reinforced by the significance value which is below 0.025 , namely 0.012 for weight loss, 0.011 for a decrease in fat percentage, and 0.010 for a decrease in waist circumference. So it can be concluded that there is a significant difference between the control group using the normal diet program and the experimental group using the low-calorie diet program with a combination of weight training with diet-assisted aerobics. It can be seen from table 7-9 that the average value of the participants' fat reduction was $11 \%$, which means that weight training combined with aerobic field assisted by a low-calorie diet program is effective in reducing body fat.

Based on the results that have been obtained (see table 3-10), the combined weight training with aerobic exercise which is assisted with a low calorie diet program is more effective than the combined weight training with aerobic exercise that is assisted with a normal diet program. In addition to exercising, by consuming foods that are low in calories, will make the remaining calories in the body into energy, thus accelerating the decline in the weak body, because calories out more than calories that enter the body. To find out which diet has the most effective effect, the analysis is continued by using the independent sample $t$-test with the result that the $t$ value is greater than $t$ table, then it is concluded that there is a difference in decreasing the percentage of fat in the normal diet and low calorie diets.

Fat can be reduced from the body by making it a source of energy. One way that energy can be produced in large quantities is to do physical exercise or exercise. However, not all physical exercise can burn fat into energy. The use of fat as energy will occur after the use of glucose as energy is not possible [33]. Changes in fat are influenced by the amount of energy expended versus the amount of energy consumed. Therefore, if energy expenditure is still low, but excessive levels of food consumption, weight gain will occur [34].

Fats produce enormous amounts of energy, this is because the amount of fat is stored in the human body. It's just that its use requires a long time because of so many processes and requires a variety of enzymes. Energy stored as fat in adipose tissue is used as a source of fuel by the body after the available energy is obtained from depleted glucose [35-37]

Exercise is a systematic process or work done repeatedly over a long period of time by increasing the training load gradually and has an individual nature. Each set of movements in the exercise is designed to improve abilities by involving energy generation and muscle activity and adapting to repetitive stimulation [38-40]. The series of movements that continues to increase in physical exercise, certainly requires great energy. The use of fat requires oxygen as a burning compound, so that efficient physical exercise to reduce fat levels is aerobic physical exercise. Aerobic exercise is an exercise that uses energy that comes from burning with oxygen so that it requires oxygen.

As stated in previous theoretical studies, combined training in weight training and aerobics is an effective form of exercise in reducing body fat percentage. Because weight training (weight training) at the beginning aims to utilize sugar energy (glycogen) which is still available in the liver and muscles more optimal, so that when doing the next exercise, aerobic exercise, the body already uses fat as the main source in minutes the first. This is in accordance with Virtuoso (2019), who stated that "Weight training is a superior way to reduce body fat and keep fat from being piled up again. Muscles cause metabolism to become more active. The more muscle you have, the faster your metabolic rate, the more calories you burn, making it easier for your body to get a slender, firmer appearance" [41]. Research with moderate intensity running exercises has shown subcutaneous fat has the most reduction, followed by subcutaneous hand and body sequences. The exercise is a moderate intensity running activity. Running movements that prioritize leg movements to move the body position 
cause the legs to move continuously. Continuous leg muscle movement causes leg muscles to use fat as an energy source and reduce foot subcutaneous fat [42, 43].

The study was conducted to compare aerobic exercise with aerobic and weight training combined exercises. Research conducted on 20 obese adults shows that both forms of exercise have a significant effect on decreasing body weight, BMI, and body fat percentage. The exercise is done 4 times a week for 8 weeks. Aerobic exercise is done using a treadmill with a target of $70 \%$ HRM training monitored by using a wireless heart rate monitor. Aerobic combination training and weight training done with aerobic exercise for 30 minutes then proceed with 10 times repetition and 2 sets of weight training. Expenses takes $70 \%$ of RM [44].

Other studies have been conducted on 119 obese samples aged 18-70 to determine the effect of weight training and or aerobic exercise on body fat. Aerobic exercise is done equivalent to 12 miles / week calories with an intensity of $60-80 \%$ VO2max; weight training is done 3 times a week; 3 sets per day with 8-12 reps per set; combination training is done with a combination of aerobic exercise and weight training. The study was conducted for 8 weeks. Body composition was measured using a Dual Energy X-ray absorptiometry machine (DEXA). The results showed the aerobic exercise group and the combination exercise group significantly reduced body mass and fat mass compared to the weight training group. However, the increase in lean body mass occurred significantly in the weight training and combination groups [45]. Previous research concluded that a combination of aerobic exercise and weight training can help reduce body fat and also help increase muscle mass so that the body becomes fitter.

To reduce the percentage of fat, a balance must be maintained between calories in and calories out. If the incoming energy is the same as the energy expended, then the weight will be maintained, if the incoming energy is greater than the energy expended, then the rest will be stored as fat so that the weight will increase. A low calorie balanced diet is a diet whose energy content is below normal requirements, enough vitamins and minerals, and enough fiber is useful in the process of weight loss [46, 47]. This diet limits energy-dense foods, such as cakes that contain lots of simple carbohydrates and fats and fried foods. In this diet while maintaining the balance of carbohydrates, fats, proteins and mineral vitamin requirements. This is consistent with the opinion (Ross, 2004; Allard, 2007; Anding: 2001; Zalilah, 2006; Layman, 2005) that "with a balanced low-calorie diet effectively decreases weight, BMI, skinfold thickness, fat mass percentage, increases percentage fat free mass, reduce waist to hip ratio, and serum leptin levels" [48-52]. So this low calorie diet is better in an effort to reduce body fat.

The study showed no significant differences between the normal diet and low calorie diets, because the control of research samples in the regulation of nutrition that has not been strict. Regarding the diet menu given because researchers have not been able to fund the nutritional needs of the sample during the study period, so that only a dietary reference from the nutritionist is given to each sample in accordance with the division of the designed diet group, then controlled by doing a food recall. Of course, in the implementation of food recall to the sample there were some deficiencies in getting data due to the competence of the research team who carried it out so that their ability to dig information from the sample was not perfect.

\section{Conclusions}

The combination of aerobic exercise and weight training can reduce participants' body weight, body fat and waist circumference, both in the normal diet and low-calorie diet groups. However, the low calorie diet program is more effective than the normal diet. This is evidenced by the significant reduction in body fat and strengthened by the independent sample t-test. According to the $t$ value, it is greater than the $\mathrm{t}$ table and the significance value obtained is less than 0.025 , namely 0.012 for weight loss, 0.011 for a decrease in the percentage of fat, and 0.010 for a decrease in waist circumference. It is concluded that there is a difference in the decrease in the percentage of fat in the normal diet and low calorie diet groups.

\section{Acknowledgements}

Thanks to all respondents who have been willing to be a sample in this study, so that this study can be completed as desired.

\section{REFERENCES}

[1] Kovesdy, C. P., Furth, S. L., Zoccali, C., \& World Kidney Day Steering Committee. (2017). Obesity and kidney disease: hidden consequences of the epidemic.

[2] Dalla Valle, M., Laatikainen, T., Kalliokoski, T., Nykänen, P., \& Jääskeläinen, J. (Childhood obesity in specialist care searching for a healthy obese child. Annals of Medicine, vol. 47, no. 8, pp. 639-654, 2015.

[3] Vignolo M, Silvestri M, Parodi A, Pistorio A, Battistini E, Rossi GA. Relationship between body mass index and asthma characteristics in a group of Italian children and adolescents. J Asthma, vol.42, no. 185, pp. 1-9. 2005

[4] Wiegand, S, Keller, K. M, Robl, M, l’Allemand, D, Reinehr, $\mathrm{T}$, Widhalm, K. Obese boys at increased risk for nonalcoholic liver disease: evaluation of 16390 overweight or obese children and adolescents. Int J Obes (Lond), vol, 34, pp.1468-1474, 2010 
[5] Finkelstein, E. A., Khavjou, O. A., Thompson, H., Trogdon, J. G., Pan, L., Sherry, B., \& Dietz, W. (2012). Obesity and severe obesity forecasts through 2030. American journal of preventive medicine, 42(6), 563-570

[6] Nagy, M. R., McGlumphy, K. C., Dopp, R., Lewis, T. C., \& Hasson, R. E. Association between asthma, obesity, and health behaviors in African American youth. Journal of Asthma, 1-11. 2019

[7] Groth SW, Rhee H, Kitzman H. Relationships among obesity, physical activity and sedentary behavior in young adolescents with and without lifetime asthma. J Asthma, vol. 53, pp. 19-24, 2016. doi:10.3109/ 02770903.2015.1063646.

[8] Ghosh JR, Bandyopadhy AR. Comparative evaluation of obesity measures: relationship with blood pressures and hypertension. Singapore Med J 2007; 48:232e5.

[9] Soham A, Kenneth JO, Kyriakos SM, Kuo YF, Karl E, James SG. The effect of obesity on disability vs mortality in older Amer- icans. Arch Intern Med, 167,774e80. 2007.

[10] Gregory LB, Alain GB, Steven S, Russell T, Karol E, Roger S, et al. 2008. The impact of obesity on cardiovascular disease risk factors and subclinical vascular disease. Arch Intern Med, 168, 928e35

[11] Y.T. Nigatu, S.A. Reijneveld, P. de Jonge, E. van Rossum, U. Bultmann. 2016. The combined effects of obesity, abdominal obesity and major depression/anxiety on health-related quality of life: the LifeLines Cohort Study, PLoS One 11, e0148871.

[12] Hasler G, Gergen PJ, Ajdacic V, Gamma A, Eich D, Rossler $\mathrm{W}$, Angst $\mathrm{J}$, et al. Asthma and body weight $€$ change: a 20-year prospective community study of young adults. Int $\mathrm{J}$ Obes, vol. 30, pp. 1111-1118, 2006. doi: 10.1038/sj.ijo.0803215.

[13] Wallace JP. Obesity, In: ACSM’s Exercise Management for Person with Chronic Diseases and Disabilities. Human Kinetics. 1997

[14] B. B, Kahn., \& J. S. Flier. Obesity and insulin resistance. The Journal of clinical investigation, vol. 106, no. 4, pp. 473-481. 2000

[15] A. J. Stunkard., M. S. Faith., \& K. C. Allison. Depression and obesity. Biological psychiatry, vol. 54, no. 3, pp. 330-337. 2003

[16] E. A. Finkelstein., O. A. Khavjou., H. Thompson., J. G. Trogdon., L. Pan., B. Sherry., \& W. Dietz. Obesity and severe obesity forecasts through 2030. American journal of preventive medicine, vol. 42, no. 6, pp. 563-570. 2012

[17] Emma Rich \& Louise Mansfield. Fat and Physical Activity: Challenging Weight Stigma Special Issue (Volume 1) of Fat Studies: An Interdisciplinary Journal of Body Weight and Society. Fat Studies, 2018. DOI: 10.1080/21604851.2019.1 552823

[18] Roost, A. C. Losing It: The Construction and Stigmatization of Obesity on Reality Television in the United States. The Journal of Popular Culture, vol. 49, no. 1, pp. 174-95, 2016. doi:10.1111/ jpcu.12377.

[19] Afriwardi. 2011. Ilmu Kedokteran Olahraga. Jakarta: Penerbit Buku Kedokteran EGC.

[20] R, Ade. Bakar Lemak Tampa Lapar Tampa Lemas. Jakarta:
Tabloid Bola. 2007

[21] Flint, S., and S. Reale. "Weight Stigma in Frequent Exercisers: Overt, Demeaning and Condescending.” Journal of Health Psychology, vol. 23, no. 5, pp. 710-719, 2018 doi:10.1177/ 1359105316656232

[22] Cohn, S. "From Health Behaviours to Health Practices: Critical Perspectives, an Introduction.” Sociology of Health \& Illness, vol. 36, no. 2, pp. 157-162, 2014. doi:10.1111/1467-9566.12140.

[23] L. Cohen., L. Manion., \& K. Morrison. Research Methods in Education: Routledge. 2007

[24] J. W, Creswell. Research Design Qualitative, Quantitative, And Mixed Method Aproach. Singapore : SAGE Publications Asia-Pacific, 2012.

[25] F. N, Kerlinger. Foundations of behavioral research. Yogyakarta: Gadjah Mada, 2014.

[26] Schutz Y, Kyle UUG, Pichard C. Fat-free mass index and fat mass index percentiles in Caucasians aged 18-98 y. Int $\mathrm{J}$ Obesity, vol. 26, pp. 953-60, 2002.

[27] Kyle UG, Bosaeus I, De Lorenzo AD, Deurenberg P, Elia M, Manuel Gómez J. ESPEN. Bioelectrical impedance analysis-part I: review of principles and methods. Clin Nutr, vol. 23, no. 5, pp. 1226-1243.

[28] Lee SY, Gallagher D. Assessment methods in human body compo-sition. Curr Opin Clin Nutr Metab Care, vol. 11, no. 5, pp. 566-572, 2008.

[29] Sivapathy, Shashikala., Chang, Chung Yuan., Chai, Wen Jin., Ang, Yee Kwang., Yim, Hip Seng. Assessment of hydration status and body composition of athlete and non-athlete subjects using Bioelectrical Impedance Analysis. Journal of Physical Education and Sport, vol. 13, no. 2, pp. $157-162,2013$

[30] Gontarev, Seryozha., Ruzdija, Kalac. The relationship between overweight, obesity and physical fitness among eleven and twelve-year-old Macedonian adolescents. Journal of Physical Education and Sport, vol. 14, no. 2, pp. $178-185,2014$.

[31] Abulmeaty MAA, Almajwal AM, Alsaif MA, Hassan HMZ, Almansour SK. 2016. Impedancemetry vs. anthropometry in the prediction of body adiposity and obesity diagnosis. Prog Nutr, vol. 18, no. 1, pp. 39-46, 2016

[32] Cramer, D. Advanced quantitative data analysis. McGraw-Hill Education (UK). 2003.

[33] Fox EL. 1993. The physiological basis exercise and sport 5th ed. USA: MW. Crown Communication,.

[34] Almeida-Suhett, C. P., Scott, J. M., Graham, A., Chen, Y., \& Deuster, P. A. Control diet in a high-fat diet study in mice: Regular chow and purified low-fat diet have similar effects on phenotypic, metabolic, and behavioral outcomes. Nutritional Neuroscience, 1-10, 2017. doi:10.1080/102841 5x.2017.1349359

[35] Ganong WF. Review of medical physiology 22th ed. USA: Appleton \& lange, 2008

[36] Hundemer JK, Nabar SP, Shriver BJ, Forman LP. Dietary fiber sources lower blood cholesterol in C57BL/6 mice. J 
Nutr, vol. 121, no. 9, pp. 1360-1365, 1991

[37] Yang Y, Smith DL, Jr., Keating KD, Allison DB, Nagy TR. Variations in body weight, food intake and body composition after long-term high-fat diet feeding in C57BL/6J mice. Obesity, vol. 22, no. 10, pp. 2147-2155, 2014

[38] H. Shirazipour, C., J. Munroe-Chandler, K., \& M. Loughead, T. Judging the gym: Stereotypes of female weight trainers. International Journal of Sport and Exercise Psychology, vol. 15, no. 4, pp. 337-350, 2016.

[39] Shields, C. A., Brawley, L. R., Martin Ginis, K. A. Interactive effects of exercise status and observer gender on the impressions formed of men. Sex Roles, vol. 56, pp. 231237, 2007. doi:10.1007/s11199-006-9166-0

[40] Shilling, C. \& Bunsell, T. From iron maiden to superwoman: The stochastic art of self-transformation and the deviant female sporting body. Qualitative Research in Sport, Exercise, and Health, vol. 6, no. 4, pp. 478- 498, 2014. doi:10.1080/2159676X.2014.928897

[41] Virtuoso, J. F., Menezes, E. C., \& Mazo, G. Z. Effect of Weight Training with Pelvic Floor Muscle Training in Elderly Women with Urinary Incontinence. Research Quarterly for Exercise and Sport, 1-10,2019. doi:10.1080/02701367.2019.1571674

[42] Lesmana, H., \& Padli, P. (2019). Studi Deskriptif Perubahan Lemak Subkutan Setelah Latihan Fisik Intensitas Moderat. Sporta Saintika, 4(1), 80-89.

[43] Gurjão, A. L. D., Gobbi, L. T. B., Carneiro, N. H., Gonçalves, R., Ferreira de Moura, R., Cyrino, E. S., Gobbi, S. Effect of strength training on rate of force development in older women. Research Quarterly for Exercise and Sport, vol. 83, no. 2, 268-275, 2012.doi:10.1080/02701367.2012.1059985 7

[44] Jin, C.-H., Rhyu, H.-S., \& Kim, J. Y. The effects of combined aerobic and resistance training on inflammatory markers in obese men. Journal of Exercise Rehabilitation, vol. 14, no 4, pp. 660-665, 2018.

[45] Willis, L. H., Slentz, C. A., Bateman, L. A., Shields, A. T. Piner, L. W., Bales, C. W., Kraus, W. E. Effects of aerobic and/or resistance training on body mass and fat mass in overweight or obese adults. Journal of Applied Physiology, vol. 113, no. 12, pp. 1831-1837, 2012.

[46] Ümüș Özbey, Serap Balaban, Zeynep Çelebi Sözener, Aslı Uçar, Dilşad Mungan \& Zeynep Misırligil (2019): The effects of diet-induced weight loss on asthma control and quality of life in obese adults with asthma: a randomized controlled trial, Journal of Asthma, 2019 DOI: 10.1080/02770903.2019.1590594

[47] Dias-Junior SA, Reis M, Carvalho-Pinto RM, Stelmach R, Halpern A, Cukier A. Effects of weight loss on asthma control in obese patients with severe asthma. Eur Respir J, vol. 43, pp. 1368-1377, 2014. doi:10.1183/ 09031936.00053413

[48] Anding JD, Suminski RR, Boss J. 2001. Dietary intake, body mass index exercise and alcohol: are college women following the dietary guide lines for Americans. J Am Coll Health, 49: 167e71.

[49] Zalilah MS, Khor GL, Mirnalini K, Norimah AK, Ang M. Dietary intake, physical activity and energy expenditure of Malaysian adolescents. Singapore Med J, 47: 491e8. 2006

[50] Layman, D. K., \& Walker, D. A. Potential importance of leucine in treatment of obesity and the metabolic syndrome. The Journal of nutrition, vol. 136, no. 1, pp. 319-323, 2006

[51] Ross, R., Janssen, I., Dawson, J., Kungl, A. M., Kuk, J. L., Wong, S. L., \& Hudson, R. Exercise-induced reduction in obesity and insulin resistance in women: a randomized controlled trial. Obesity research, vol. 12, no. 5, pp. 789-798, 2004.

[52] Allard, J. Should nutritional status be routinely assessed and corrected before bariatric surgery?. Nature Clinical Practice Gastroenterology \& Hepatology, vol. 4, no. 3, pp. 130-131, 2007. 